\title{
Urgences
}

\section{La dernière y restera}

\section{Michel Savard}

Numéro 15, octobre 1986

Épigraphiques

URI : https://id.erudit.org/iderudit/025306ar

DOI : https://doi.org/10.7202/025306ar

Aller au sommaire du numéro

Éditeur(s)

Urgences

ISSN

0226-9554 (imprimé)

1927-3924 (numérique)

Découvrir la revue

Citer ce document

Savard, M. (1986). La dernière y restera. Urgences, (15), 39-39.

https://doi.org/10.7202/025306ar

Ce document est protégé par la loi sur le droit d'auteur. L’utilisation des services d'Érudit (y compris la reproduction) est assujettie à sa politique d'utilisation que vous pouvez consulter en ligne.

https://apropos.erudit.org/fr/usagers/politique-dutilisation/
Cet article est diffusé et préservé par Érudit.

Érudit est un consortium interuniversitaire sans but lucratif composé de l’Université de Montréal, l'Université Laval et l'Université du Québec à Montréal. Il a pour mission la promotion et la valorisation de la recherche. https://www.erudit.org/fr/ 


\section{Michel Savard LA DERNIËRE Y RESTERA}

Passez entre les fleurs et regardez:

Au bout du pré c'est le charnier

Eugène Guillevic: "Les charniers", dans Exécutoire

à Michel Beaulieu

celle qui

d'entre toutes

t'a vu naître et te consumer

sous la question des origines

tu n'y revenais toujours qu'au terme

d'un plus grand épuisement jurant

que jamais plus tu ne la quitterais

malgré l'inanité de la formule que deux

trois semaines plus tard tu remettrais

en cause lues et classées les plaquettes

dont t'aurait rejoint la dernière caisse

et tu glisserais dans la conversation

ce projet du Japon cette expédition

toujours remise et tous les guides qu'un

par un tu avais consultés de la première

à la dernière page teinte d'effroi

cette fascination de l'Orient tu

te la seras vu refuser d'un coup

de café (l'heure sans doute tardive)

et de chaleur comme souvent la ville

y succombe elle-même

en cette saison 